\title{
The Brazilian Society of Cerebrovascular Diseases - history
}

\author{
Sociedade Brasileira de Doenças Cerebrovasculares - histórico \\ Rubens José Gagliardi', Cesar Noronha Raffin², Jorge El Kadum Noujaim³, Aroldo Luiz Silva Bacellar4, \\ Gabriel Rodriguez de Freitas ${ }^{5}$, Jamary Oliveira-Filho, Sheila Cristina O. Martins ${ }^{7,8}$, Gisele Sampaio Silva ${ }^{9,10}$, \\ Octávio Marques Pontes-Neto ${ }^{11}$
}

\begin{abstract}
The present article provides the historical background of the Sociedade Brasileira de Doenças Cerebrovasculares (Brazilian Society for Cerebrovascular Diseases), including details on its function, structure, challenges and main achievements.

Keywords: Stroke; history; societies, scientific; neurology.

\section{RESUMO}

O presente texto apresenta um relato histórico da Sociedade Brasileira de Doenças Cerebrovasculares, incluindo detalhes da sua fundação, estruturação, dificuldades e principais realizações.
\end{abstract}

Palavras-chave: Acidente vascular cerebral; história; sociedades científicas; neurologia.

The Sociedade Brasileira de Doenças Cerebrovasculares (SBDCV) encompasses the Scientific Department of Cerebrovascular Diseases of the Brazilian Academy of Neurology (ABN), and is, therefore, the body that represents specialists in cerebrovascular diseases in Brazil.

The SBDCV was spawned from the Working Group in Cerebrovascular Pathology of the $\mathrm{ABN}$, the name formerly used by the $A B N$ to group scholars of different subspecialties. These working groups are now referred to as Scientific Departments, whose mission it is to foster scientific development and help organize Brazilian Neurology meetings.

\section{BEGINNINGS}

The Cerebrovascular Diseases Working Group was set up in 1982, under the leadership of Prof. Dr. Roberto Melaragno Filho, an eminent neurologist deeply involved with cerebrovascular diseases. Professor Melaragno was tasked with the initial structuring of the group of neurologists interested in cerebrovascular diseases. This working group had the following coordinators, with two-year tenures:

1982-1984 Roberto Melaragno Filho

1984-1986 Sylvio Saraiva

\footnotetext{
`Santa Casa de São Paulo, Faculdade de Ciências Médicas, Departamento de Medicina, Disciplina de Neurologia, São Paulo SP, Brasil; ${ }^{2}$ Hospital Meridional Cariacica, Grande Vitória ES, Brasil;

${ }^{3}$ Hospital dos Serviços do Estado, Departamento de Neurologia, Rio de Janeiro RJ, Brasil;

${ }^{4}$ Hospital São Rafael, Serviço de Neurologia, Salvador BA, Brasil;

5 Universidade Federal Fluminense, Instituto D’Or de Pesquisa e Ensino (IDOR), Departamento de Neurologia, Rio de Janeiro RJ, Brasil;

${ }^{6}$ Universidade Federal da Bahia, Programa de Pós-Graduação em Ciências da Saúde, Salvador BA, Brasil;

${ }^{7}$ Universidade Federal do Rio Grande do Sul, Hospital de Clínicas de Porto Alegre e Hospital Moinhos de Vento, Porto Alegre RS, Brasil;

${ }^{8}$ Universidade Federal do Rio Grande do Sul, Hospital Moinhos de Vento, Porto Alegre RS, Brasil;

๑Universidade Federal de São Paulo, Disciplina de Neurologia, São Paulo SP, Brasil;

${ }^{10}$ Hospital Israelita Albert Einstein, Programa Integrado de Neurologia, São Paulo SP, Brasil;

${ }^{11}$ Universidade de São Paulo, Faculdade de Medicina de Ribeirão Preto, Departamento de Neurociências e Ciências do Comportamento, Ribeirão Preto SP, Brasil.

Rubens José Gagliardi (iD) https://orcid.org/0000-0002-3497-0174

Correspondence: Rubens José Gagliardi; Irmandade da Santa Casa de Misericórdia de São Paulo, Pavilhão Conde de Lara; Rua: Dr. Cezário Motta Jr, 112 / $3^{\circ}$ andar;01221-020 São Paulo SP, Brasil; E-mail: rubensjg@apm.org.br

Conflict of interest: There is no conflict of interest to declare.

Received 28 June 2018; Received in final form 20 August 2018; Accepted 26 September 2018.
} 
1986-1988 Sylvio Saraiva

1988-1990 Roberto Melaragno Filho

1990-1992 José Ivan Cipoli Ribeiro

1992-1994 Rubens José Gagliardi

The working group was active but the need for greater involvement of specialists became clear. Few neurologists were interested in cerebrovascular diseases and the level of communication and tasks was lower than we wished. We recognized the need to solidify studies of cerebrovascular diseases; we needed to be more connected and to encourage neurologists to join our working group.

\section{Creation of the SBDCV}

Early in 1994, the board of the working group established new directions, widening the scope of the working group, and proposed setting up the SBDCV to address the above-mentioned challenges. Initially, all members of the ABN were sent a letter (Figure 1) about the creation of the SBDCV, informing them that this would be part of the Cerebrovascular Diseases

\section{SOCIEDADE BRASILEIRA DE DOENCAS CÉREBRO-VASCULARES \\ SOCIEDADE BRASILEIRA DE DOENÇAS CEREBRO-VASCULARES}

Prezadu colega.

OGrupo de Trabalho em Patologia Vascular Cerebral da Academia Brasileira de Neurologia. visando melhor definição de seus propósitos e maior facilidade de comunicação entre os neurologistas brasileiros e as entidades congêneres internacionais, optou por assumir nova identidade, passando a ser chamada de Sociedade Brasileira de Doenças Cérebro-Vascular.

Esta nova Socitedade terá como objetivos prioritários agregar os colegas que se interessam pelo estudo destas doenças, facilitar e agilizar o intercâmbio de informaçōes nesta área da neurologia, divulgar pesquisas, apoiar estudos multicêntricos e manter contato con as principais sociedades internacionais de "stroke". Isto permiturá melhor conhecimento do trabalho que está sendo desenvolvido em nosso meio e das nossas necessidades e: ou deficiências. Permitira também acesso mais rápido às pesquisas estrangeiras e abrirá un canal que poderá facilitar a participação de trabalhos brasileiros em publicaçōes ou congressos do setor

A Sociedade Brasileira de Doenças Cérebro-Vasculares será o grupo de trabalho de Patologia Vascular Cerebral, um órgão da Academia Brasileira de Neurologia que acompanhará as determinaçōes e normas comuns aos grupos de trabalho. Com isto, ficará mais fácil o contato com todos os neurologistas e a divulgaçāo conjunta de informaçōes. Pretenderá editar periodicamente boletins, ("newsletter") acompanhando uma tendência das congêneres internacionais, onde se dará énfase as pesquisas em andamento, programaf̧öes científicas, textos de ordem genérica e assuntos gerais pertinentes à área. Realizará ou patrocinará simpósios ou "meetings", para atualização e reciclagem.

Caso o colega se interesse pela área e queira pertencer ativamente à Sociedade, escreva para a Academia Brasileira de Neurologia, (Al. Raja Gabaglia, 235 CEP 04551-000 São Paulo, SP). A/C da SBDCV, solicitando a sua inscrição provisória e nós remeteremos uma cópia dos estatutos e maiores informações. Enviem também sugestões, que serão muito bem vindas e estudadas.

Esperamos que esta Sociedade venha a ocupar o espaço que lhe é reservado e cumpra os seus propósitos. O seu futuro depende de todos nós.

Abraços.

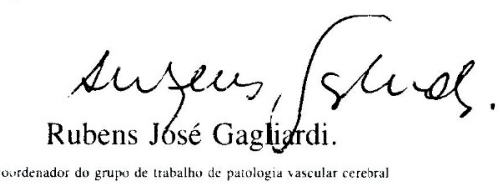




\title{
mararkminum 325830

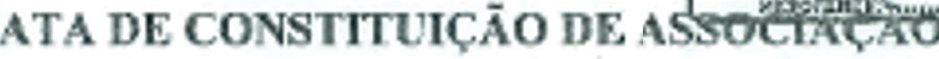

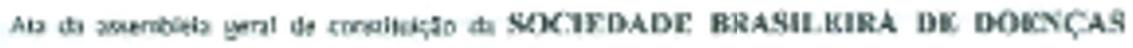

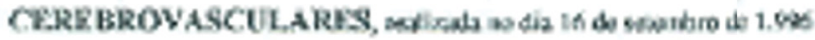

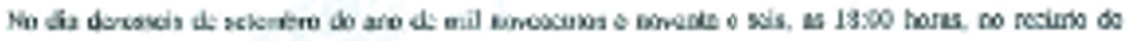

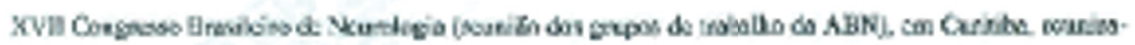

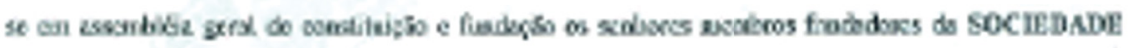

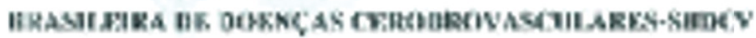

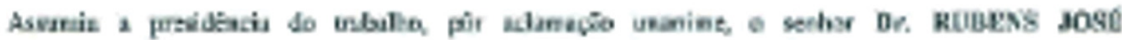

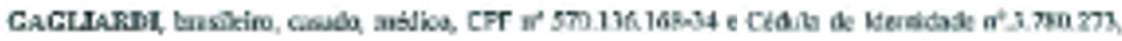

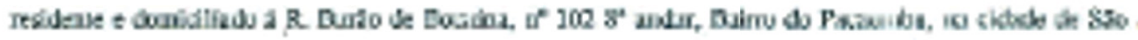

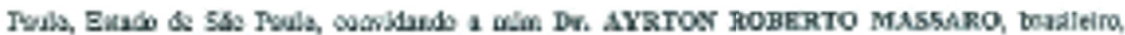

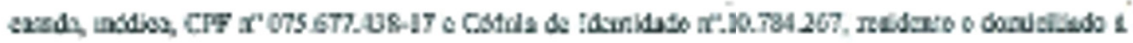

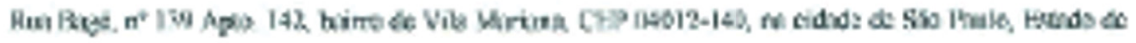

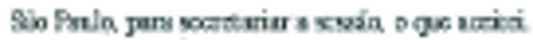

Figure 2. Registry of constitution.

\section{CAPJTLLO ]l DAS FINALIDADES}

\author{
Artigo 1) $\mathrm{d}^{*}$

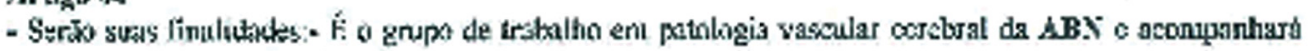 \\ todas as normas cos GT da $\mathbf{A B N}$ \\ fx maphitns deva Sxciedade Non:

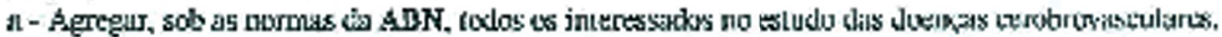

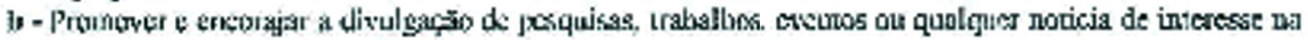

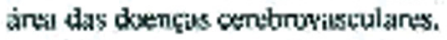 \\ c - Coloboras en pesquieas da áres. \\ d - Promorer o ilprimoramento texnicy e tientilituo.

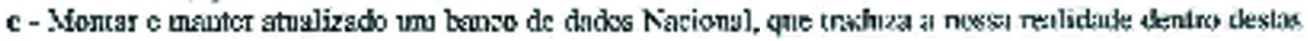 \\ dichas

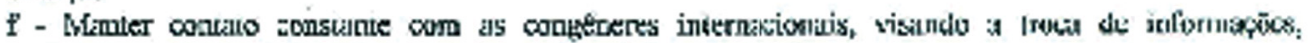

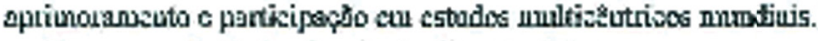 \\ g- Pronover utividades de oriedtapies pural leigce.

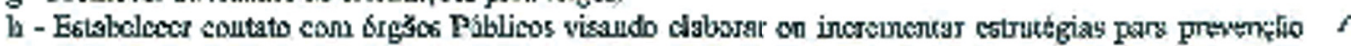 \\ dectis doenças:
}

Figure 3. Proposal.

Working Group, contribute to the $\mathrm{ABN}$ and comply with all regulatory rules. The beginning of 1994 marked the actual founding date of the SBDCV, while the society was formally instituted on the September 16, 1996, following its registration at the notary public office (Figure 2) and approval of the decision on its constitution at the Annual General Meeting of the working group held in Curitiba during the XVIII Brazilian Congress of Neurology. At this time, a call to all ABN members was made. At the AGM, the articles of incorporation, and the setting out of the main objectives of the SBDCV, were approved (Figure 3). 
Another important discussion at the meeting was the analysis of the best name for the disease, since some advocated "encephalic vascular accident" as opposed to "cerebrovascular accident"; the meeting elected the best terminology to be: "cerebrovascular accident", as this was more widely recognized and used.

\section{Challenges and support}

Although the articles of incorporation state that the SBDCV would be the working group of the ABN, abide by its regulations and would evolve within the $\mathrm{ABN}$, there were reservations on the part of the $\mathrm{ABN}$ involving concerns over separate growth of the SBDCV and its consequent distancing from the $A B N$. This was not the intention of the new society, yet this concern almost led to the demise of this fledgling association. At the time, there was pivotal support from Professor Antonio Spina-França Neto, a former president of the $\mathrm{ABN}$ and one of the most respected neurologists, who backed the continuation of this idea. Professor Sérgio Novis then also supported the idea of setting up the SBDCV, which took shape little by little.

\section{Directors of the SBDCV}

The management boards of the SBDCV, from its founding to the present day, have had the following presidents:

1996-2000 Rubens José Gagliardi

2000-2004 Cesar Noronha Raffin

2004-2006 Jorge El Kadum Noujaim

2006-2008 Aroldo Luiz S. Bacellar

2008-2010 Gabriel Rodriguez de Freitas

2010-2012 Jamary Oliveira-Filho

2012-2104 Sheila Cristina O. Martins

2014-2016 Gisele Sampaio Silva

2016-2018 Octávio Marques Pontes-Neto

\section{Main actions of the SBDCV}

The SBDCV has carried out a range of activities, with key actions including: national consensus, congresses, teaching books, collaborative national and international studies, and the heading of campaigns on awareness, prevention and rehabilitation of stroke in Brazil.

The first communication disseminated by the SBDCV was the publication in the form of a four-monthly information release called the "Newsletter", starting in January 2004, and containing abstracts of studies and research, local and international news, congresses, opinions of colleagues, etc. This initial milestone was fundamental for the ABN and SBDCV and prompted other publications, including those in other neurology subspecialties.

A number of book titles were released, under the SBDCV, on topics such as: cardiovascular diseases, management approaches; approaches in the acute phase of stroke, and Stroke Brazil.

\section{Congresses of the SBDCV}

The Annual General Meeting of the ABN in Curitiba (1996) approved the holding of the biannual Brazilian Congress on Cerebrovascular Diseases. It was decided to hold the first congress in São Paulo, November 13-15, 1997, in which 426 delegates took part, including eight overseas invitees. This represented a strong foundation and provided encouragement for further events, which have been held regularly ever since. To date, the following congresses have been held:

$1^{\text {st }}$ Congress, 1997: São Paulo (SP)

Chair: Rubens José Gagliardi

$2^{\text {nd }}$ Congress, 1999: Caldas Novas (GO)

Chair: Sebastião Eurico Melo-Souza

$3^{\text {rd }}$ Congress, 2001: Rio de Janeiro (RJ) Chair: Jorge El-Kadum Noujaim

$4^{\text {th }}$ Congress, 2003: Porto Alegre (RS) Chair: Sérgio Roberto Haussen

$5^{\text {th }}$ Congress, 2005: Salvador (BA) Chair: Aroldo Luiz S. Bacellar

$6^{\text {th }}$ Congress: 2007 Joinville (SC) Chair: Alexandre Luiz Longo

$7^{\text {th }}$ Congress, 2009: Vitoria (ES) Chair: Cesar Noronha Raffin

$8^{\text {th }}$ Congress, 2011: Gramado (RS) Chair: Maurício Friedrich

$9^{\text {th }}$ Congress, 2013: Fortaleza (CE) Chair João José Freitas de Carvalho

$10^{\text {th }}$ Congress, 2015: Belo Horizonte (MG) Chair: Romeu Vale Sant'Anna

$11^{\text {th }}$ Congress, 2017 Salvador (BA) Chair: Bruno Bacellar Pedreira

These congresses have contributed greatly to the increase in study of cerebrovascular diseases in Brazil, promoting education on stroke, information exchange, the dissemination of studies and awards, recognition and elucidation of the current situation in Brazil, contribution of guidelines, among other positive outcomes. In this segment of activities, another major event promoted by the SBDCV was the securing of the World Stroke Congress for Brazil in 2012. This represented a concerted effort by a group of colleagues. The congress was held in Brasilia on October 10-13, 2012. It was chaired by Dr. Ayrton Massaro (Brazil) and Dr. Bo Norving (Sweden), and the local organizing committee comprised the following specialists: Elza Dias Tosta, Sheila Cristina O. Martins, Cesar Noronha Raffin, Linamara Rizzo Batistela and Rubens José Gagliardi. This event, besides technical advancement, allowed the dissemination of information about our society at an international level.

\section{Consensus and guidelines of the SBDCV}

Another highly-important activity performed by the SBDCV is the devising of "Consensus" and "Guidelines". 


\title{
$a$ \\ World Stroke \\ Organization
}

wso oniers

trenitent

C. Normine sonster

Nenpreserets

Y. Hachiociandes

imestaso has hadsen

C. A. Domen kapress

twaแm

M Bvers Arvit

Mentes net lexe

Monver uss

who aeart ed phecoss

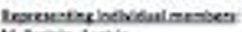

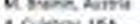

ravens usa

5. K Dwh. Antully.

unowe va

v. Hachenai Conde

W reac Cermere

a cuss fonas

Miscones

Hivin Frase

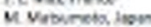

a. narving sences

a comations

CPlichersesper

P. Sincuesco, ux

e wave onis

Wi. Wre town

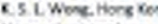

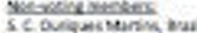

w cone Spotikets

Insceset-reselemileascieles:

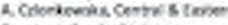

Gupansace seceny

Monse, onmassacer seony

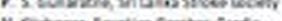

sestere tostin cerbociastio

mesliranscivar

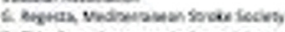

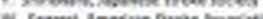

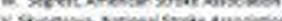

at kacias hovesion

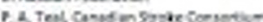

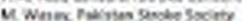

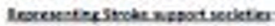

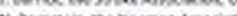

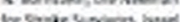

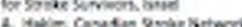

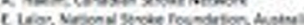

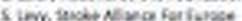

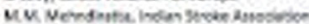

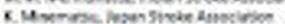

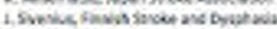

nasiviser

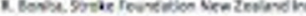

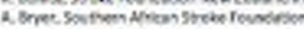

\author{
Dr Sheila Martins \\ Df Jamary Fihe Olveira \\ Dr Gabricl Freitas \\ Brazilian Stroke Society/Brazlian Stroke \\ Netwcokerazilian Acacemy of Neurclogy \\ Erazilion Sroke Associajor \\ Rua lteroce, 2is 5ala 307 \\ Brazil
}

Geneva, 15 Docember 2011

Desar Sheila, Jamary and Gabric,

On behalt of the Worid Stroke Crganization (WSO), we would Ike to cangraxlate you for being selected as the First Place/Cold Prize recipient of the World Stroke Day 2011 Awards. We were impressed with how you were able to mobilize communitics through oducation and media. In particular, we would lke to commend you for the innovefive partnershios than you were able to cutivale with the Ministry of Healith and with local soocer feams.

A cortificate of resognition will be given to you at the Opering Ceramony af the Werld Stroke Cangress in Brasilat on the evening of 10 October 2012. In this regard, we would be gratelul if there could be semeone whe cen gosect the WSO prize on behalt of your assccistion. Morecrer, the Intemstend Joumal of Stroke (WS) may also wart 00 have a phane imerview with you in the caming monthe. The interview may be featured in one of the upcoming LSS issuca. For your infermstion, the other World Sroke Day 2011 laureshes are:

$\rightarrow$ Sesend Rlacesiver Award

- Neeman Association for Stroke Survivors - |srael

$\rightarrow$ Thind Placeriecnze Awand

e Mangolan Stroke Association

Should you have questions or require additional information, please do not hesitate to get in contact wth JJ Divino, Seniar Campaigns Officer, at WSO Secretariar in Genevs.

Thank you for your dedicstion and commitmem to fighng stroke and you continuod innovation in stroks awsrencss.

Yaurs sinceroly,

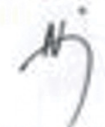

Be Norving, MD, PhD

President

Work Stroke Conganization

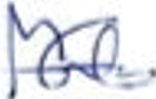

Markku Kase, MD, PhD, FAHA, FESO

Chairperson, World Stroke Campaign

World Sroke Organizaron

\section{Wonib sTage casumanov \\ Letministrafive orfies

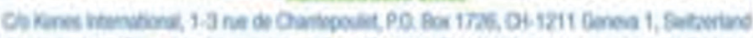

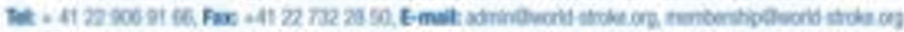

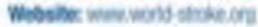

Figure 4. Letter of World Stroke Organization.

So far, a total of eight consensus and guidelines have been produced and published in the journal Arquivos de Neuro-Psiquiatria ${ }^{1-8}$ :

Treatment of the acute phase of ischemic stroke $-2001^{1}$

Thrombolysis in stroke $-2002^{2}$

Neuroprotection in stroke $-2005^{3}$
Treating carotid disease in the acute phase of stroke $-2005^{4}$

Management of the acute phase of hemorrhagic stroke $-2009^{5}$

Treatment of the acute phase of ischemic stroke. Part I - $2012^{6}$

Treatment of the acute phase of ischemic stroke. Part II - $2012^{7}$ 
Endovascular treatment (mechanical thrombectomy) - $2017^{8}$

\section{Stroke prevention programs}

One of the purposes of the SBDCV is to raise the awareness in the lay public of the importance of recognizing a stroke, risks of having a stroke, how to prevent it and how to proceed in the event of a stroke. This has been achieved via talks for the public and publications, but mainly through participation in the "World Stroke Day" campaign". This is an international activity coordinated by the World Stroke Organization, in which the SBDCV is engaged and coordinates nationally. This has been held annually, uninterrupted, since 2005, in different cities in Brazil. The campaign in Brazil has proven to be a huge success. In 2011, the SBDCV-ABN won first place in the World Stroke Day Awards and ranked second in 2009, 2012 and 2015. The letter sent by Dr. Stephen Davis, President of the World Stroke Organization to Dr. Sheila Martins, who headed the national campaign in 2011, can be seen in Figure 4.

\section{Contributions to the Brazilian Ministry of Health and to the Federal Board of Medicine}

Given its main objectives of prevention and proper treatment of stroke in Brazil, since its founding, the SBDCV has worked with the Brazilian government to collaborate in the implementation of regulations and actions on this front. We were involved in the drafting of numerous important regulations, including those on guidelines for diagnosing brain death ${ }^{10}$, line of care in stroke ${ }^{11}$, rulings 664 and 665 on thrombosis, and on the establishment of stroke units ${ }^{12,13}$. Another conquest was the inclusion of neurologists in the group of interventionists.

In parallel, the SBDCV has played an active role in lobbying for improved public healthcare for stroke patients in Brazil ${ }^{14}$.

\section{Other activities}

There are several groups that have been working on providing new data on the epidemiology of stroke in Brazil. Dr. Norberto Cabral is one of the leading members of this group, with important contributions. His papers have contributed to a better understanding of the social disparities of our stroke patients, and the alerting of the International Stroke Society.

The relationship with the Ministry of Health began in 2008, with Dr. Sheila Cristina O. Martins as the lead person. She has made major contributions to improving stroke awareness among politicians and the Brazilian population, as well as fostering the inclusion of tPA as treatment of acute ischemic stroke by the National Healthcare System of Brazil.

Transcranial Doppler ultrasonography has a leading person in the country. Dr. Viviane Zétola has made several contributions, including the certification of neurologists to perform the technique.

The inclusion of intensive care as an area closely connected to cerebrovascular diseases in the Society has been an important achievement. Drs. Jamary Oliveira-Filho and Gisele Sampaio Silva are two major leaders who have helped in this approach.

\section{FINAL COMMENTS}

This article outlines some of the SBDCV's activities and its path to success, which have contributed to further studying of cerebrovascular diseases in Brazil, and consolidated our position in relation to international organizations. The journey of the SBDCV will be long-lasting and ongoing, given the collaboration of renowned colleagues and the new values they bring to the Society. The SBDCV shall continue to grow, while maintaining its important role in national and international Neurology.

\section{References}

1. Sociedade Brasileira de Doenças Cerebrovasculares. Brazilian guideline for the management of acute stroke. Arq Neuropsiquiatr. 2001;59(4):972-80. Portuguese. http://dx.doi.org/10.1590/S0004-282X2001000600026

2. Sociedade Brasileira de Doenças Cerebrovasculares. [Brazilian consensus for the thrombolysis in acute ischemic stroke]. Arq Neuropsiquiatr. 2002;60(3A):675-80. Portuguese. https://doi.org/10.1590/S0004-282X2002000400032

3. Freitas GR, Noujaim JE, Hausen SR, Yamamoto FJ, Novak EM, Gagliardi RJ. Neuroproteção no acidente vascular cerebral. opinião nacional. Arq Neuropsiquiatr. 2005;63(3B):880-91. https://doi.org/10.1590/S0004-282X2005000500035

4. Gagliardi RJ, André C, Fukujima MM, Melo-Souza SE, Zétola VF. [Management of carotid disease in acute phase of stroke: national opinion]. Arq Neuropsiquiatr. 2005 Sep;63(3A):709-12. Portuguese. https://doi.org/10.1590/S0004-282X2005000400032

5. Pontes-Neto OM, Oliveira-Filho J, Valiente R, Friedrich M, Pedreira B, Rodrigues BC et al. [Brazilian guidelines for the manegement of intracerebral hemorrhage]. Arq Neuropsiquiatr. 2009 Sep;67(3B):940-50. Portuguese. https://doi.org/10.1590/S0004-282X2009000500034

6. Oliveira-Filho J, Martins SC, Pontes-Neto OM, Longo A, Evaristo EF, Carvalho JJ et al. Guidelines for acute ischemic stroke treatment: part I. Arq Neuropsiquiatr. 2012 Aug;70(8):621-9. https://doi.org/10.1590/S0004-282X2012000800012

7. Martins SC, Freitas GR, Pontes-Neto OM, Pieri A, Moro CH, Jesus PA et al. Guidelines for acute ischemic stroke treatment: part II: stroke treatment. Arq Neuropsiquiatr. 2012 Nov;70(11):885-93. https://doi.org/10.1590/S0004-282X2012001100012

8. Pontes-Neto OM, Cougo P, Martins SC, Abud DG, Nogueira RG, Miranda $\mathrm{M}$ et al. Brazilian guidelines for endovascular treatment of patients with acute ischemic stroke. Arq Neuropsiquiatr. 2017 Jan;75(1):50-6. https://doi.org/10.1590/0004-282x20160174

9. Gomes AB, Henrique Junior M, Schoeps VA, Santos MM, Pellegrinelli A, Matos BP, et al. Popular stroke knowledge in Brazil: A multicenter survey during “World Stroke Day”. eNeurologicalSci. 2016 Dec;6:63-7. 
10. Conselho Federal de Medicina - CFM. Resolução No 1.480/1997, de 08/08/1997. Diário Oficial União. 21 ago 1997.

11. Ministério da Saúde (BR). A linha de cuidado em acidente vascular cerebral nas rede de atençâo às urgencia e emergencia. 2012 [CITED 2017 Sep 15]. Available from: http://conitec.gov.br/images/ Protocolos/pcdt-cuidados-AVC.pdf

12. Ministério da Saúde (BR). Portaria No.664, de 12 de abril de 2012. Aprova o Protocolo clínico e diretrizes terapêuticas - trombólise no acidente vascular cerebral isquêmico agudo. 2012 [cited 2017 Aug 9]. Available from: http://bvsms.saude.gov.br/bvs/saudelegis/ gm/2012/PRT0664_12_04_2012.html
13. Ministério da Saúde (BR). Portaria No 665, de 12 de abril de 2012. Dispõe sobre os critérios de habilitação dos estabelecimentos hospitalares como Centro de Atendimento de Urgência aos Pacientes com Acidente Vascular Cerebral (AVC), no âmbito do Sistema Único de Saúde (SUS), institui o respectivo incentivo financeiro e aprova a Linha de Cuidados em AVC. 2012 [cited 2017 Dec 02]. Available from: http://bvsms.saude.gov.br/bvs/saudelegis/ gm/2012/PRT0665_12_04_2012.html

14. Martins SC, Pontes-Neto OM, Alves CV, Freitas GR, Oiliveira Filho J, Tosta ED,et al. Past, presente and future of stroke in middle-income countries: the Brazilian experience. Int J Stroke. 2013;8(supply A100):106-11. https://doi.org/10.1111/ijs.12062. 